\title{
PELANGgARAN KAMPANYE PEMILIHAN UMUM PERSPEKTIF FIKIH JINÂYAH
}

\author{
Farid Maulana Ramadhani \\ Pascasarjana Universitas Widyagama JI. Borobudur Blimbing Malang | \\ farid.mauladhanil2@gmail.com
}

\begin{abstract}
This study highlights the Islamic political jurisprudence's against violations of the general election campaign. The violations of the campaign com Islamic political jurisprudence's perspective mitted by the perpetrators to elect the members of DPR and DPD is something that is familiar to the public. It means that there have so often a violation of the campaign during the legislative election campaign. Although the campaign's provisions in Law No. 8 year 2012 on General Election has been set on the prohibition of the campaign and the implementation of a safe election campaign. The campaigners look like clossing their eyes on the rules of the campaign. So that, it is quite difficult to be followed up by the authorities and the perpetrators are so easy to perform the prohibited action. Based on the Islamic political jurisprudence's perspective, the election campaign violations committed by the perpetrators have some negative effects that harm and disturb the public order. So that the perpetrators can be sentenced by an educative punishment for a criminal offense that has not been determined by the shari'ah.
\end{abstract}

Keywords: Abuse, campaign, general election, Islamic political jurisprudence.

Abstrak: Artikel ini membahas tentang tinjauan Fiqh Jinâyah terhadap pelanggaran kampanye Pemilu. Pelanggaran kampanye pemilu yang dilakukan oleh pelaku kampanye dalam pemilihan umum anggota DPR, DPD, DPRD merupakan suatu hal yang tidak asing lagi bagi masyarakat, dalam artian begitu seringnya terjadi suatu pelanggaran kampanye pada masa kampanye pemilu legislatif. Walaupun pada ketentuan kampanye dalam Undang-undang Nomor 8 Tahun 2012 tentang Pemilihan Umum sudah mengatur mengenai larangan kampanye dan pelaksanaan kampanye pemilu yang tertib dan aman, para pelaku kampanye seperti tutup mata atas aturan kampanye 
tersebut dan ketika terjadi suatu pelanggaran begitu sulit ditindak lanjuti oleh pihak yang berwenang sehingga para pelaku begitu mudah untuk melakukan suatu tindakan yang dilarang. Dalam pandangan fiqh jinâyah, pelanggaran kampanye pemilu yang dilakukan oleh pelaku kampanye ini memiliki efek negatif yang merugikan masyarakat karena sudah mengganggu ketertiban umum. Sehingga pelaku dapat dijatuhi hukuman ta'zir yang sifatnya mendidik dan merupakan hukuman bagi tindak pidana yang belum ditentukan oleh syarak.

Kata Kunci: Pelanggaran, kampanye, pemilihan umum, fikih jinâyah

\section{Pendahuluan}

Sejak Indonesia merdeka, telah beberapa kali Indonesia melaksanakan Pemilihan Umum (PEMILU) sebagai salah satu wujud dari kedaulatan rakyat dan demokrasi. Terhitung sudah sebelas kali Indonesia menyelenggaran Pemilu, yaitu: pertama, Pemilu 1955, kedua Pemilu 1971, ketiga Pemilu 1977, keempat Pemilu 1982, kelima Pemilu 1987, keenam Pemilu 1992, ketujuh Pemilu 1997, kedelapan Pemilu 1999, kesembilan Pemilu 2004, ${ }^{1}$ kesepuluh Pemilu 2009, dan kesebelas Pemilu 2014. Beberapa Pemilu yang telah dilakukan oleh bangsa Indonesia tersebut telah memberikan pengalaman dan pelajaran yang berharga bagi Bangsa Indonesia terutama dalam mengatur sistem Pemilu.

Kehadiran Pemilu merupakan salah satu sarana atas demokratisasi politik di Indonesia. ${ }^{2}$ Pemilu menjadi penting karena megandung beberapa intisari di dalamnya, yakni Pertama, Pemilu merupakan wahana bagi tegaknya demokrasi dan hukum; Kedua, Pemilu adalah media artikulasi politik rakyat; Ketiga, Pemilu diselenggarakan untuk menjadi media bagi kontrak sosial antara rakyat dan pemimpinnya, dan; Keempat, Pemilu diselenggarakan dengan menggunakan dana yang tidak kecil. ${ }^{3}$ Arbi Sanit juga menyimpulkan, bahwa pada dasarnya Pemilu

' Titik Triwulan Tutik, Konstruksi Hukum Tata Negara Indonesia Pasca Amandemen UUD 1945, (Jakarta: Kencana, 20 I I), 343.

2 M. Karim Rusli, Pemilu Demokratis Kompetitif, (Yogyakatra : PT. Tiara Wacana, 1991), 29.

3 Muhaki, "Mekanisme Suara Terbanyak bagi Pemilu Legislatif (Studi Siyasah Dusturiyah)", AlDaulah Jurnal Hukum dan Perundangan Islam, Vol. I, No. 2, Tahun 20I I, 148. 
memiliki empat fungsi utama, yakni 1) sebagai pembentukan legitimasi penguasa dan pemerintah; 2) sebagai pembentuk perwakilan politik rakyat; 3) sirkulasi elite penguasa; dan 4) sebagai pendidikan politik. ${ }^{4}$

Penyelenggaraan Pemilu secara fair menjadi sangat penting, karena Pemilu itu sendiri merupakan sarana utama bagi demokrasi, dan sekaligus perwujudan kehendak rakyat. Apabila terselenggaranya Pemilu banyak diwarnai dengan kecurangankecurangan didalamnya, maka kehendak rakyat yang sesungguhnya bakal tidak terwujud. Kemudian tujuan atau sasaran tidak langsung dari Pemilu berupa pembudayaan dan pelembagaan politik (termasuk didalamnya demokrasi) akan tidak tercapai. ${ }^{5}$ Hal demikian dapat dilihat pada pelaksanaan kampanye Pemilu yang terjadi di Indonesia saat ini. Pelaksanaan kampanye Pemilu telah menjadi suatu hal yang harus dilaksanakan, karena telah tercantum didalam Undang-Undang Nomor 8 Tahun 2012. Disana, dijelaskan bahwa kampanye merupakan pendidikan politik bagi masyarakat dan juga berperan sebagai komunikasi politik terhadap publik.

Di sisi lain, kampanye Pemilu merupakan proses mempersuasi khalayak untuk bersedia menerima, mendukung, dan akumulasinya adalah memilih partai atau kandidat yang dikampanyekan. ${ }^{6}$ Dalam kegiatannya, kampanye Pemilu yang tujuannya menarik suara sebanyak mungkin tidak sekedar melibatkan rakyat yang individu maupun kelompok dalam berfikir. Keterlibatan emosional terhadap partai atau tokoh yang ditampilkan, sering memainkan peranan kunci bagi keputusan seseorang untuk menentukan pilihannya. Dalam hal ini menyebabkan pelaksanaan demokrasi selalu mengandung unsur "huru-hara" yang tercermin dari diadakan pawai kampanye. ${ }^{7}$

\footnotetext{
${ }^{4}$ Arbi Sanit, Partai, Pemilu dan Demokrasi, (Jakarta : Pustaka Pelajar, 1997), 158.

${ }^{5}$ Perulian Donald, Menggugat Pemilu, (Jakarta: Pustaka Sinar Harapan, 1997), 13.

${ }^{6}$ M. Khoirul Anwar, Vina Selviana, Perilaku Partai Politik, (Malang: UMM Press, 2006), 45.

${ }^{7}$ Riswandha Imawan, Membedah Politik Orde Baru, (Yogyakarta: Pustaka Pelajar, 1998), 3-5.
}

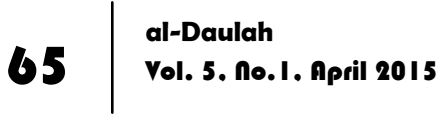


Seiring berjalannya waktu dan semakin banyaknya pelaku pelanggaran dan berbagai macam kecurangan dalam Pemilu terutama mengenai pelanggaran kampanye Pemilu. Karena pada dasarnya pelaksanaan kampanye Pemilu sudah banyak diatur dalam Undang-undang, salah satunya Undang-undang Nomor 10 Tahun 2008 tentang Pemilu yang sekarang sudah diganti sesuai dengan tuntutan dan dinamika perkembangan masyarakat menjadi Undang-undang nomor 8 tahun 2012. ${ }^{8}$

Dalam Undang-undang Nomor 10 Tahun 2008 mengatur ketentuan pidana bagi pelaku tindak pidana Pemilu yang diatur dalam Bab XXI, yaitu pasal 260 sampai dengan pasal 311. Adapun tindak pidana Pemilu yang berkaitan dengan tahapan kampanye Pemilu, dana kampanye, maupun larangan-larangan dalam berkampanye terdapat pada pasal 269 sampai dengan pasal282. Sedangkan pada Undang-undang nomor 8 tahun 2012 yang mengatur ketentuan pidananya bagi pelaku tindak pidana Pemilu diatur dalam Bab XXII, yaitu pasal 273 sampai dengan pasal 291. Tindak pidana yang berkaitan dengan tahapan kampanye Pemilu, dana kampanye, maupun larangan-larangan dalam berkampanye terdapat pada pasal 275 sampai dengan pasal 280.

Walaupun sudah diatur dengan Undang-undang, tetapi masih banyak terjadi pelanggaran dan kecurangan baik menyangkut partai politik dan perorangan. Sehingga dapat disimpulkan adanya suatu pelanggaran bararti tidak ada ketaatan terhadap Undang-undang yang dibuat dan disahkan oleh DPR dan MPR. ${ }^{9}$ Di sisi lain kedua lembaga tersebut merupakan perwakilan dari seluruh rakyat Indonesia, yang mempunyai wewenang mengatur seluruh kebijakan negara. Setiap kali diadakan pemilihan umum di Indonesia, selalu terjadi tindak pidana pelanggaran Pemilu khususnya pelanggaran kampanye

${ }^{8}$ Lihat Undang-undang Nomor 8 Tahun 2012 tentang Pemilihan Umum Anggota Dewan Perwakilan Rakyat, Dewan Perwakilan Daerah, Dewan Perwakilan Rakyat Daerah.

${ }^{9}$ Priyanto, "Analisis Hukum Islam terhadap pelanggaran Undang-undang nomor 31 tahun 2002 tentang Partai Politik dan Undang-Undang I 2 tahun 2003 tentang Pemilu" (Skripsi-- IAIN Sunan Ampel, Surabaya, 2004), 3. 
atau melanggar atauran kampanye yang dilakukan oleh beberapa partai politik atau calon anggota legislatif walaupun peraturan perundang-undangan dengan tegas melarang perbuatan yang digolongkan kedalam perbuatan tindak pidana Pemilu.

Contoh salah satu kasus tindak pidana Pemilu merupakan pelanggaran jadwal kampanye atau biasa disebut dengan curi start kampanye yang terdapat di Jawa Tengah. ${ }^{10}$ Pelanggaran terjadi saat acara halalbihalal yang digelar PKPI di Gunungpati, Semarang, pada tanggal 1 September 2013, terdapat ajakan untuk memilih oleh Sutiyoso. Sutiyoso terbukti dengan sengaja melakukan kampanye rapat umum di luar jadwal sebagai mana diatur dalam pasal 276 Undang-undang Nomor 8 tahun 2012 tentang Pemilu. Jaksa Penuntut Umum (JPU) Bambang Rukun jaga menyatakan bahwa mantan Gubernur DKI Jakarta itu terbukti melanggar Pasal 276 Undang-Undang Nomor 8 Tahun 2012 tentang Pemilu DPR, DPD, dan DPRD. PN Semarang langsung menjatuhkan hukuman percobaan terhadap Sutiyoso dalam kasus pelanggaran kampanye rapat umum di luar jadwal sesuai Undang-undang Nomor 8 tahun 2012 tentang pemilihan anggota DPR, DPD, dan DPRD. Kasus ini dapat menjadi pelajaran bagi petugas pengawas Pemilu di daerah lain, bahwa jika ada himbauan dari petugas (Panitia pengawas Pemilu atau Panwaslu) yang tidak diindahkan, maka dapat dibawa ke jalur hukum.

Dalam Islam, kampanye memiliki kesamaan dengan dakwah, baik dakwah kepada yang baik maupun dakwah kepada yang

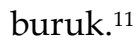

Allah swt berfirman dalam surah An Nahl ayat 125:

"Serulah (manusia) kepada jalan Tuhan-mu dengan hikmah"12 dan pelajaran yang baik dan bantahlah mereka dengan cara

\footnotetext{
${ }^{10}$ Faizurrahman, Republika, "Curi Start Kampanye, Caleg PKPI Divonis Satu Bulan Penjara" dalam http://www.beritadewan.com/divonis-curi-start-kampanye-sutiyoso-tuntut-yang-beriklan-ditelevisi-juga-ditindak/, diakses pada 20 Maret 2014.

"Wahdanal Haq, "Kampanye dalam Islam" dalam http://wahdanalhaq.blogspot.com/20 I//0I/kampanye-dalam-islam/, diakses pada 05 April 2014.
} 
yang baik. Sesungguhnya Tuhanmu Dialah yang lebih mengetahui tentang siapa yang tersesat dari jalan-Nya dan Dialah yang lebih mengetahui orang-orang yang mendapat petunjuk." 13

Adapun dalam hukum pidana Islam apabila melakukan kampanye yang di luar ketentuan yang berlaku disebut juga sebuah pelanggaran, pelanggaran dalam hukum pidana islam dapat disebut sebagai jarimah. terdapat beberapa macam pelanggaran atau jarimah dalam hukum pidana islam, diantaranya yaitu: jarîmah hudūd, jarîmah qisas diyat dan jarîmah ta'zîr dari ketiga macam pelanggaran tersebut dapat di ambil contoh misalkan pelaku jarimah yang dikenakan sanksi $t a^{\prime} z \hat{i} r$. Sifat yang menjadi alasan dikenakannya hukuman atas perbuatan ta'zîr adalah dikarenakan merugikan kepentingan umum. Selain itu intisari atas jarîmah ta'zîr dibagi menjadi tiga bagian yakni; 1) Ta'zîr karena melakukan perbuatan maksiat, 2) Ta'zîr karena melakukan perbuatan yang membahayakan kepentingan umum, serta 3) Ta'zîr karena melakukan pelanggaran (mukhâlafah). Dari intisari jarîmah ta'zîr tersebut, maka dapat dikatakan suatu pelanggaran dalam hukum pidana islam pasti dikenakan sanksi, meskipun pelanggaran tersebut tidak termasuk atau keleuar dari ketentuan nas atau hak Allah.

Dalam pembahasan penelitian ini, penulis memfokuskan jarîmah ta'zîr yang dikarenakan melakukan pelanggaran (mukhâlafah) dan perbuatan yang merugikan kepentingan umum. Sehingga masalah pelanggaran kampanye Pemilu ini semakin menarik untuk dibahas, karena dalam prakteknya tidak jarang kita jumpai penyimpangan-penyimpangan seperti halnya salah satu contoh, melakukan kampanye lebih awal atau diluar jadwal kampanye yang dilakukan oleh partai-partai politik dan calon

\footnotetext{
${ }^{12}$ Hikmah ialah Perkataan yang tegas dan benar yang dapat membedakan antara yang hak dengan yang bathil.

13 Yayasan Penyelenggara Penterjemah dan Pentafsir Al-Qur'an, Al-Qur'an dan Terjemanya, (Jakarta: 197I), 42I.
} 
anggota legislatif sehingga keluar dari aturan Undang-undang yang ada. Untuk itu perlu adanya penelitian Tinjauan Figh Jinâyah terhadap Pelanggaran Kampanye Pemilu Dalam Undang-undang Nomor 8 Tahun 2012 tentang Pemilihan Umum.

\section{Pengertian Pelanggaran Kampanye Pemilu}

Sampai saat ini tidak ada definisi yang diberikan oleh peraturan perundang-undangan di Indonesia mengenai apa yang disebut dengan pelanggaran kampanye pemilu atau juga bisa disebut dengan tindak pidana pemilihan umum. Dalam Kitab Undang-Undang Hukum Pidana (KUHP) Indonesia telah termuat lima pasal yaitu pasal 148, 149, 150, 151, 152 KUHP yang subtansinya tindak pidana pemilu namun tanpa menyebutkan sama sekali pengertian dari pelanggaran kampanye pemilu atau tindak pidana pemilu. Begitu pula dalam beberapa Undangundang Pemilu yang pernah berlaku di Indonesia, khususnya Undang-undang Nomor 8 tahun 2012, hanya memuat larangan dalam kampanye dan ketentuan pidananya tetapi tidak memberi definisi apa yang disebut dengan pelanggaran kampanye pemilu. Akan tetapi Undang-undang nomor 8 tahun 2012 telah menjelaskan secara rinci apa yang dimaksud dengan pengertian kampanye pemilu beserta bentuk-bentuk pelanggaran pemilu. Oleh karena itu maka penulis akan memaparkan beberapa definisi secara umum mengenai pelanggaran kampanye pemilu, seperti apa yang dimaksud dengan pelanggaran dan apa yang dimaksud dengan kampanye pemilu secara satu-persatu.

Pelanggaran dapat didefinisikan sebagai perbuatan (perkara) yang melanggar peraturan yang ditetapkan ${ }^{14}$. Terjadinya pelanggaran dalam setiap kegiatan tidak bisa terhindarkan karena pelanggaran dapat terjadi ketika adanya unsur kesengajaan maupun karena kelalaian. Pelanggaran dapat dilakukan banyak 
pihak bahkan dapat dikatakan semua orang memiliki potensi untuk melakukan pelanggaran.

Dalam Undang-undang pemilu yang berlaku, ketentuan pidana yang terdapat dalam Undang-undang Pemilu ini terdapat dua macam jenis yaitu pelanggaran dan kejahatan ${ }^{15}$, yang mana perbuatan tersebut sudah termasuk melanggar hukum atau melanggar aturan yang berlaku. Sedangkan definisi dari pelanggaran itu sendiri dalam kamus besar Bahasa Insonesia yaitu perbuatan tindak pidana yang lebih ringan dibanding kejahatan atau peristiwa yang sudah disidangkan di pengadilan. ${ }^{16}$ Pelanggaran ini sendiri juga merupakan perbuatan yang hanya dilarang oleh peraturan perundangan namun tidak memberikan efek yang tidak berpengaruh secara langsung kepada orang lain. Seperti halnya konvoi kampanye pemilu yang biasanya dilaksanakan di jalan raya dengan tidak menggunakan helm bagi pengendara sepeda motor.

Sedangkan pelanggaran menurut Kitab Undang-undang Hukum Pidana (KUHP) adalah perbuatan pidana yang ringan, ancaman hukumannya berupa denda atau kurungan. Semua perbuatan pidana yang tergolong pelanggaran diatur dalam buku III KUHP. Misalkan, pelanggaran terhadap keamanan umum bagi orang, barang dan kesehatan umum yang diatur dalam pasal 498502. ${ }^{17}$

Berangkat dari beberapa definisi yang telah dipaparkan di atas, maka pelanggaran itu sendiri merupakan perilaku yang menyimpang untuk melakukan tindakan menurut kehendak sendiri tanpa memperhatikan peraturan yang telah diperbuat. Dalam kegiatan kampanye pemilihan umum, pelanggaran secara konsep didefinisikan sebagai perbuatan pidana yang tergolong tidak seberat kejahatan ${ }^{18}$. atau dapat diartikan sebagai perbuatan

\footnotetext{
${ }^{15}$ Undang-undang Nomor 8 Tahun 2012 tentang Pemilihan Umum anggota DPR, DPD, DPRD

${ }^{16}$ Mohammad Ali, http://www.kamusbahasaindonesia.org/pelanggaran diunduh pada tanggal 3006-2014

${ }^{17}$ Andi Hamzah, KUHP dan KUHAP, (Jakarta, Rineka Cipta, 2003), 198- 199.

${ }^{18}$ Ainul Yaqin, http://www. blogger.com/post- diunduh pada tanggal 20-06-20I 4.
} 
yang melanggar peraturan dan perundang-undangan dalam pemilu.

Perihal Kampanye, menurut Kotler dan Roberto, kampanye ialah sebuah upaya yang diorganisasi oleh satu kelompok (agen perubahan) yang ditujukan untuk memersuasi target sasaran agar bisa menerima, memodifikasi atau membuang ide, sikap dan perilaku tertentu. ${ }^{19}$ Oleh karena itu, kampanye bisa dikatakan sebagai tindakan komunikasi yang terorganisir yang diarahkan pada khalayak tertentu, pada periode tertentu guna mencapai tujuan tertentu. ${ }^{20}$

Di dalam Undang-Undang Pemilu sendiri, Kampanye pemilu diartikan sebagai kegiatan peserta pemilu untuk meyakinkan para pemilih dengan menawarkan visi, misi, dan program peserta pemilu. ${ }^{21}$ Dalam kampanye pemilu anggota Dewan Perwakilan Rakyat (DPR), Dewan Perwakilan Daerah (DPD), Dewan Perwakilan Rakyat Daerah (DPRD) ini bertujuan untuk meyakinkan para pemilih dalam memperoleh dukungan sebesarbesarnya dan semaksimal mungkin, dengan menawarkan visi, misi dan program masing-masing calon anggota legislatif DPR, DPD, dan DPRD. Untuk anggota DPR atau DPRD baik itu kabupaten atau kota maupun provinsi, kampanye dilaksanakan pengurus parpol, calon legislatif, juru kampanye orang-seorang dan organisasi yang ditunjuk misalnya sayap parpol. ${ }^{22}$ Sedangkan untuk calon anggota DPD, pelaksananya orang-seorang, dan organisasi yang ditunjuk. ${ }^{23}$

Dari definisi kampanye pemilu secara umum tersebut dapat mencakup keseluruhan proses dan fenomena praktek kampanye yang terjadi di lapangan. Pada dasarnya kampanye pemilu

${ }^{19}$ Hafied Cangara, Komunikasi Politik: Konsep, Teori dan Strategi, (Jakarta: Rajawali Pers, 20I I), 229.

${ }^{20}$ Gun Gun Heryanto, Komunikasi Politik Sebuah Pengantar, (Bogor: Ghalia Indonesia, 2013$), 8$.

21 Undang-undang Nomor 8 Tahun 2012 tentang Pemilihan Umum Anggota DPR, DPD, DPRD, pasal I.

${ }^{22}$ Ibid., pasal 79.

${ }^{23} \mathrm{Ibid}$. 
merupakan bagian dari pendidikan dan dilaksanakan secara bertanggung jawab yang dapat dilakukan melalui metode kampanye diantaranya adalah: ${ }^{24}$

1. Pertemuan Terbatas

2. Pertemuan tatap muka

3. Penyebaran bahan kampanye pemilu kepada umum

4. Pemasangan alat peraga di tempat umum

5. Iklan media cetak dan media massa elektronik

6. Rapat umum

7. Kegiatan lain yang tidak melanggar larangan kampanye pemilu dan ketentuan peraturan perundang-undangan

Selain itu, sifat kampanye pada dasarnya terbagi menjadi dua, yakni kampanye negatif dan kampanye hitam (black campaign). Kampanye negatif adalah kampanye yang sifatnya menyerang pihak lain melalui sejumlah data atau fakta yang bisa diverifikasi dan diperdebatkan. Dan Kampanye hitam (Black campaign) adalah kampanye yang bersumber pada rumor, gossip, bahkan menjurus ke implementasi sejumlah teknik propaganda. Jenis ini biasanya sulit untuk diverifikasi apalagi diperdebatkan. Jadi pada dasarnya kampanye merupakan hal lumrah yang sering ditemukan. Bahkan dalam beberapa waktu sering kali ditemukan implementasi dari proses kampanye yang tidak sejalan dengan regulasi yang telah disepakati bersama.

Dari beberapa definisi di atas mengenai pelanggaran dan kampanye, penulis dapat menyimpulkan bahwasannya pelanggaran kampanye pemilu adalah suatu perilaku atau tindakan kampanye yang menyalahi aturan terkait tata cara berkampanye dalam Undang-undang Pemilu legislatif yang dilakukan oleh pelaku kampanye dan hukumannya tergolong ringan.

${ }^{24}$ Ibid., Pasal 82. 


\section{Bentuk Pelanggaran Kampanye Pemilu}

Dalam tinjauan mengenai pelanggaran-pelanggaran selama kampanye pemilu calon legislatif DPR, DPD, dan DPRD, pihak panwaslu dan bawaslu telah memberikan aturan mengenai pelanggaran-pelanggaran yang didasarkan pada Undang-undang Nomor 8 Tahun 2012 mengatur terhadap bentuk pelanggaran yang dapat diklasifikasikan terhadap pelanggaran kampanye Pemilu.

1. Pelanggaran administrasi

Dalam Undang-undang pemilu yang dimaksud pelanggaran adminitratisi adalah pelanggaran yang meliputi tata cara, prosedur, dan mekanisme yang berkaitan dengan administrasi pelaksanaan Pemilu dalam setiap tahapan penyelenggaraan Pemilu di luar tindak pidana Pemilu dan pelanggaran kode etik penyelenggara Pemilu. ${ }^{25}$ Dan juga dapat dikatakan pelanggaran terhadap ketentuan Undang-undang Pemilu yang tidak termasuk dalam ketentuan pidana pemilu dan ketentuan lain yang diatur dalam peraturan KPU, dengan demikian maka semua jenis pelanggaran, kecuali yang telah ditetapkan sebagai tindak pidana, termasuk dalam kategori pelanggaran administrasi. Misalnya menggunakan fasilitas pemerintah, tempat ibadah dan tempat pendidikan untuk berkampanye, tidak melaporkan dana awal kampanye, pemantau pemilu melanggar kewajiban dan larangan. Ketentuan dan persyaratan menurut undang-undang pemilu tentu saja bisa berupa ketentuan-ketentuan dan persyaratanpersyaratan yang diatur, baik dalam undang-undang pemilu maupun dalam keputusan-keputusan Komisi pemilihan Umum (KPU) yang bersifat mengatur sebagai aturan pelaksanaan dari undang-undang pemilu. ${ }^{26}$

Dalam hal penyelesaian pada pelanggaran administrasi pemilu ini, undang-undang pemilu menyatakan bahwa laporan yang merupakan pelanggaran administrasi diserahkan kepada

${ }^{25}$ Ibid., pasal 253.

${ }^{26}$ Ramlan Surbakti dkk, Penanganan Pelanggaran Pemilu, (Jakarta: Kemitraan, 20I I), 16.

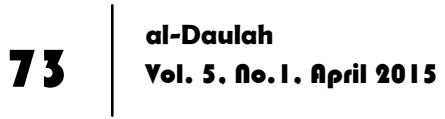


KPU. Jika sebelumnya diatur bahwa laporan pelanggaran pemilu disampaikan paling lama hari sejak terjadinya pelanggaran pemilu, sekarang batas waktu pelaporan tersebut diperpanjang durasinya menjadi laporan pelanggaran pemilu disampaikan paling lama 7 hari sejak diketahui dan/atau ditemukannya pelanggaran Pemilu. Sedangkan lamanya waktu penanganan laporan pelanggaran pemilu oleh jajaran pengawas pemilu tidak mengalami perubahan, yaitu pengawas pemilu wajib menindaklanjuti laporan paling lama 3 hari setelah laporan diterima. Namun, dalam hal pengawas pemilu memerlukan keterangan tambahan dari pelapor, maka tindak lanjut penanganan laporan pelanggaran pemilu dilakukan paling lama 5 hari setelah laporan diterima.

Setelah pengawas pemilu menerima dan mengkaji laporan pelanggaran yang masuk, maka pengawas pemilu akan pengkategorisasikan laporan pelanggaran tersebut apaka masuk dalam pelangggaran administrasi pemilu, atau keluar dari pelanggaran administrasi.

Mengenai penyelesaian pelanggaran administrasi pemilu ini sudah dijelaskan dan diatur secara rinci dalam Undang-undang nomor 8 tahun 2012 pada bab XXI, bagian kedua, paragraf 2 pasal 254, 255, dan pasal 256.

\section{Pasal 249}

(1) Bawaslu, Bawaslu Provinsi, Panwaslu Kabupaten/Kota, Panwaslu Kecamatan, Pengawas Pemilu Lapangan dan Pengawas Pemilu Luar Negeri menerima laporan pelanggaran Pemilu pada setiap tahapan penyelenggaraan Pemilu.

(2) Laporan pelanggaran Pemilu sebagaimana dimaksud pada ayat (1) dapat disampaikan oleh:

a. Warga Negara Indonesia yang mempunyai hak pilih;

b. pemantau Pemilu; atau

c. Peserta Pemilu. 
(5) Dalam hal laporan pelanggaran Pemilu sebagaimana dimaksud pada ayat (2) telah dikaji dan terbukti kebenarannya, Bawaslu, Bawaslu Provinsi, Panwaslu Kabupaten/Kota, Panwaslu Kecamatan, Pengawas Pemilu Lapangan dan Pengawas Pemilu Luar Negeri wajib menindaklanjuti laporan paling lama 3 (tiga) hari setelah laporan diterima.

Pasal 254

(1) Bawaslu, Bawaslu Provinsi, Panwaslu Kabupaten/Kota membuat rekomendasi atas hasil kajiannya sebagaimanadimaksud pada Pasal 249 ayat (5) terkait pelanggaranadministrasi Pemilu.

(2) KPU, KPU Provinsi, KPU Kabupaten/Kota wajibmenindaklanjuti rekomendasi Bawaslu, Bawaslu Provinsi,dan Panwaslu Kabupaten/Kota sebagaimana dimaksudpada ayat (1).

(3) KPU, KPU Provinsi, KPU Kabupaten/Kota menyelesaikan pelanggaran administrasi Pemilu berdasarkan rekomendasi Bawaslu, Bawaslu Provinsi, dan Panwaslu Kabupaten/Kota sesuai dengan tingkatannya.

Pasal 255

(1) KPU, KPU Provinsi, KPU Kabupaten/Kota memeriksa dan memutus pelanggaran administrasi sebagaimana dimaksud pada Pasal 254 ayat (2) paling lama 7 (tujuh) hari sejak diterimanya rekomendasi Bawaslu, Bawaslu Provinsi, dan Panwaslu Kabupaten/Kota.

(2) Ketentuan lebih lanjut mengenai tata cara penyelesaian pelanggaran administrasi Pemilu diatur dalam Peraturan KPU. Pasal 256

Dalam hal KPU, KPU Provinsi, KPU Kabupaten/Kota, PPK, PPS atau Peserta Pemilu tidak menindak lanjuti rekomendasi Bawaslu sebagaimana dimaksud dalam Pasal 255, Bawaslu memberikan sanksi peringatan lisan atau peringatan tertulis.

2. Pelanggaran tindak pidana 
Tindak pidana Pemilu adalah tindak pidana pelanggaran dan atau kejahatan terhadap ketentuan tindak pidana Pemilu sebagaimana diatur dalam Undang-Undang ini. ${ }^{27}$ Pelanggaran tindak pidana merupakan tindakan yang dalam Undang-undang Pemilu diancam dengan sanksi pidana. Sebagai contoh tindak pidana pemilu adalah sengaja menghilangkan hak pilih orang lain, menghalangi orang lain memberikan hak suara dan mengubah hasil suara.

Dengan definisi pelanggaran tindak pidana yang telah dipaparkan tersebut diatas, maka dari definisi tersebut terbagi menjadi dua mengenai pelanggaran tindak pidana pemilu di antaranya yaitu: ${ }^{28}$

a. Tindak pidana pemilu khusus adalah tindak pidana yang berkaitan dengan pemilu dan dilaksanakan dan diselesaikan pada tahapan penyelenggaraan pemilu baik yang diatur dalam undang-undang pemilu maupun undang-undang tindak pidana pemilu. Dengan demikian maka semua jenis pelanggaran, kecuali yang telah ditetapkan sebagai tindak pidana, termasuk dalam kategori pelanggaran administrasi, dimana pelanggaran administrasi pemilu diselesaikan oleh KPU, KPU Provinsi, dan KPU Kabupaten/Kota sesuai dengan tingkatannya.

b. Tindak pidana pemilu umum adalah semua tindak pidana yang berkaitan dengan pemilu dan dilaksanakan pada tahap penyelenggaraan pemilu baik yang diatur dalam undangundang pemilu maupun undang-undang tindak pidana pemilu dan menyelesaikannya diluar tahapan pemilu. Maka proses penyelesaian tindak pidana pemilu dilakukan oleh lembaga penegak hukum yang ada yaitu kepolisian, kejaksaan, dan pengadilan.

27 Ibid., 260.

28 Dedi Mulyadi, Perbandingan Tindak Pidana Pemilu Legislatif Dalam Perpektif Hukum di Indonesia, (Bandung: Refika Aditama, 2013), 212. 
Penyelesaian pelanggaran pidana pemilu dilaksanakan melalui pengadilan dalam lingkungan peradilan umum. Penegak hukum yang berperan dalam penyelesaian tindak pidana pemilu adalah kepolisisan, kejaksaan, dan pengadilan. Dalam pemilu, kepolisisan bertugas dan berwenang melakukan penyidikan terhadap laporan atau temuan tindak pidana pemilu yang diterima dari pengawas pemilu dan menyampaikan berkas perkara kepada penuntut umum sesuai waktu yang ditentukan. Penuntut umum bertugas dan berwenang melimpahkan berkas perkara tindak pidana pemilu yang disampaikan oleh penyidik atau polri ke pengadilan sesuai waktu yang ditentukan.

Perkara tindak pidana pemilu diselesaikan oleh peradilan umum, di tingkat pertama oleh pengadilan negeri, di tingkat banding dan terakhir oleh pengadilan tinggi. Pengadilan negeri dan pengadilan tinggi memeriksa, mengadili dan memutus perkara tindak pidana pemilu menggunakan kitab UndangUndang Acara Pidana (KUHAP), ditambah beberapa ketentuan khusus dalam undang-undang pemilu. Pemeriksaan dilakukan oleh hakim khusus, yaitu hakim karir yang ditetapkan secara khusus untuk memeriksa, mengadili, dan memutus perkara pidana pemilu. Putusan pengadilan tinggi tidak dapat dilakukan upaya hukum lain.

Mengenai penyelesaian pelanggaran pidana pemilu juga sudah dijelaskan dan diatur secara rinci dalam Undang-undang nomor 8 tahun 2012 pada bab XXI, bagian keempat, paragraf 2 pasal 261, 262, 263, 264, dan pasal 265.

Pasal 261

(1) Penyidik Kepolisian Negara Republik Indonesia menyampaikan hasil penyidikannya disertai berkas perkara kepada penuntut umum paling lama 14 (empat belas) hari sejak diterimanya laporan.

(2) Dalam hal hasil penyidikan belum lengkap, dalam waktu paling lama 3 (tiga) hari penuntut umum mengembalikan berkas perkara kepada Penyidik 
Kepolisian Negara Republik Indonesia disertai petunjuk tentang hal yang harus dilakukan untuk dilengkapi.

(3) Penyidik Kepolisian Negara Republik Indonesia dalam waktu paling lama 3 (tiga) hari sejak tanggal penerimaan berkas sebagaimana dimaksud pada ayat (2) harus sudah menyampaikan kembali berkas perkara tersebut kepada penuntut umum.

(4) Penuntut umum melimpahkan berkas perkara sebagaimana dimaksud pada ayat (1) dan ayat (3) kepada pengadilan negeri paling lama 5 (lima) hari sejak menerima berkas perkara.

\section{Pasal 262}

(1) Pengadilan negeri dalam memeriksa, mengadili, dan memutus perkara tindak pidana Pemilu menggunakan Kitab Undang-Undang Hukum Acara Pidana, kecuali ditentukan lain dalam Undang-Undang ini.

(2) Sidang pemeriksaan perkara tindak pidana Pemilu sebagaimana dimaksud pada ayat (1) dilakukan oleh majelis khusus.

\section{Pasal 263}

(1) Pengadilan negeri memeriksa, mengadili, dan memutus perkara tindak pidana Pemilu paling lama 7 (tujuh) hari setelah pelimpahan berkas perkara.

(2) Dalam hal putusan pengadilan sebagaimana dimaksud pada ayat (1) diajukan banding, permohonan banding diajukan paling lama 3 (tiga) hari setelah putusan dibacakan.

(3) Pengadilan negeri melimpahkan berkas perkara permohonan banding kepada pengadilan tinggi paling lama 3 (tiga) hari setelah permohonan banding diterima.

(4) Pengadilan tinggi memeriksa dan memutus perkara banding sebagaimana dimaksud pada ayat (2) paling lama 7 (tujuh) hari setelah permohonan banding diterima. 
(5) Putusan pengadilan tinggi sebagaimana dimaksud pada ayat (4) merupakan putusan terakhir dan mengikat serta tidak dapat dilakukan upaya hukum lain.

\section{Pasal 264}

(1) Putusan pengadilan sebagaimana dimaksud dalam Pasal 263 ayat (1) dan ayat (4) harus sudah disampaikan kepada penuntut umum paling lambat 3 (tiga) hari setelah putusan dibacakan.

(2) Putusan pengadilan sebagaimana dimaksud dalam Pasal 263 harus dilaksanakan paling lambat 3 (tiga) hari setelah putusan diterima oleh jaksa.

\section{Pasal 265}

(1) Putusan pengadilan terhadap kasus tindak pidana Pemilu yang menurut Undang-Undang ini dapat memengaruhi perolehan suara Peserta Pemilu harus sudah selesai paling lama 5 (lima) hari sebelum KPU menetapkan hasil Pemilu secara nasional.

(2) KPU, KPU Provinsi, dan KPU Kabupaten/Kota wajib menindaklanjuti putusan pengadilan sebagaimana dimaksud pada ayat (1).

(3) Salinan putusan pengadilan sebagaimana dimaksud pada ayat (1) harus sudah diterima KPU, KPU Provinsi, atau KPU Kabupaten/Kota dan Peserta Pemilu pada hari putusan pengadilan tersebut dibacakan.

\section{Ketentuan Pidana Pelanggaran Kampanye Pemilu}

Undang-undang nomor 8 tahun 2012 mengkategorisasi antara tindak pidana yang berupa pelanggaran dengan tindak pidana berupa kejahatan, beserta segala sifat yang menyertainya. Selain itu juga terdapat perubahan pengaturan ketentuan pidana, dimana dalam Undang-undang ini dilakukan penghapusan atas ketentuan pidana minimum. Penghapusan ketentuan pidana minimum ini supaya Pemilu dilakukan dalam rangka memberikan asas 
kepastian hukum dan memudahkan bagi hakim dalam memberikan putusan.

Beberapa ketentuan yang tertuang dalam UU No. 8 Tahun 2012 tersebut semestinya harus dipahami dan dimengerti oleh berbagai pihak yang berkepentingan sehingga dapat dilaksanakan dengan baik dan tercipta Pemilihan Umum yang berkualitas. Adapun ketentuan pidana pelanggaran kampanye yang telah diatur dalam undang ini terdapat pada bab XXII, yaitu sebagai berikut:

1. Mengacau, menghalangi atau mengganggu jalannya kampanye (pasal 275)

Setiap orang yang mengacaukan, menghalangi, atau mengganggu jalannya Kampanye Pemilu dipidana dengan pidana kurungan paling lama 1 (satu) tahun dan denda paling banyak Rp12.000.000,00 (dua belas juta rupiah).

Penjelasan: Cukup jelas

2. Melakukan kampanye Pemilu lebih awal (pasal 276)

Setiap orang yang dengan sengaja melakukan Kampanye Pemilu di luar jadwal yang telah ditetapkan oleh KPU, KPU Provinsi, dan KPU Kabupaten/Kota untuk setiap Peserta Pemilu sebagaimana dimaksud dalam Pasal 83 ayat (2), dipidana dengan pidana kurungan paling lama 1 (satu) tahun dan denda paling banyak Rp12.000.000,00 (dua belas juta rupiah).

Untuk ketentuan dan aturan jadwal kampanye sebagaimana dimaksud dalam pasal ini yaitu kampanye pemilu yang melalui iklan media massa cetak dan media masssa elektronik beserta rapat umum yang dilaksanakan selama 21 (dua puluh satu) hari dan berakhir sampai dengan dimulainya masa tenang, masa tenang yang dimaksud berlangsung selama 3 (tiga) hari sebelum pemungutan suara.

3. Pelaksana Kampanye Pemilu yang melanggar larangan kampanye (pasal 277) 
Setiap pelaksana Kampanye Pemilu yang melanggar larangan sebagaimana dimaksud dalam Pasal 86 ayat (2) dipidana dengan pidana kurungan paling lama 1 (satu) tahun dan denda paling banyak Rp12.000.000,00 (dua belas juta rupiah).

Dalam penjelasan ketentuan pidana yang dimaksud diatas apabila pelaksana kampanye mengikut sertakan Ketua, Wakil Ketua, ketua muda, hakim agung pada Mahkamah Agung, dan hakim padda semua badan peradilan di bawah Mahkamah Agung, dan hakim konstitusi pada Mahkamah konstitusi. Ketua, Wakil Ketua, dan anggota Badan Pemeriksa Keuangan. Gubernur, Deputi Gubernur Senior, dan deputi gubernur Bank Indonesia. Direksi, komisaris, dewan pengawas, dan karyawan Badan Usaha Milik Negara atau Badan Usaha Milik Daerah. Pegawai Negri Sipil. Anggota Tentara Nasional Indonesia dan Kepolisian Negara Republik Indonesia. Kepala desa. Perangkat desa. Jadi dalam pasal ini ditujukan kepada pelaksana kampanye yang sudah mengajak atau menyertakan orang-orang yang dilarang dalam berkampanye, karena pelaksana kampanye sudah melanggar aturan yang sudah ditentukan.

4. Aparat negara yang ikut serta dalam berkampanye Pemilu (pasal 278)

Setiap pegawai negeri sipil, anggota Tentara Nasional Indonesia dan Kepolisian Negara Republik Indonesia, kepala desa, dan perangkat desa yang melanggar larangan sebagaimana dimaksud dalam Pasal 86 ayat (3) dipidana dengan pidana kurungan paling lama 1 (satu) tahun dan denda paling banyak Rp12.000.000,00 (dua belas juta rupiah).

Isi dalam ketentuan pidana pasal 278 ini memang tidak jauh berbeda dengan ketentuan pidana pada pasal 277, akan tetapi pada pasal 278 ini lebih mengacu dan lebih dikhususkan kepada PNS, TNI, POLRI, Kepala desa, dan perangkat desa pada keikut sertaan langsung tanpa ajakan dari pelaksana kampanye. 
5. Pelaksana, peserta, dan petugas kampanye yang dengan sengaja atau lalai mengakibatkan terganggunya pelaksanaan kampanye di tingkat desa atau kelurahan (pasal 279)

(1) Pelaksana kampanye, peserta kampanye, dan petugas kampanye yang dengan sengaja mengakibatkan terganggunya pelaksanaan Kampanye Pemilu di tingkat desa atau nama lain/kelurahan dipidana dengan pidana kurungan paling lama 1 (satu) tahun dan denda paling banyak Rp12.000.000,00 (dua belas juta rupiah).

(2) Pelaksana kampanye, peserta kampanye, dan petugas kampanye yang karena kelalaiannya mengakibatkan terganggunya pelaksanaan Kampanye Pemilu di tingkat desa atau nama lain/kelurahan dipidana dengan pidana kurungan paling lama 6 (enam) bulan dan denda paling banyak Rp6.000.000,00 (enam juta rupiah).

Pelaksana Kampanye Pemilu anggota DPR, DPRD Provinsi dan DPRD Kabupaten/Kota adalah pengurus partai politik, calon anggota DPR, DPRD Provinsi, DPRD Kabupaten/Kota, juru kampanye, orang-seorang, dan organisasi yang ditunjuk oleh Peserta Pemilu anggota DPR, DPRD Provinsi dan DPRD Kabupaten/Kota, wajib didaftarkan kepada KPU sesuai tingkatannya sejak sejak 3 (tiga) hari setelah Partai Politik dditetapkan sebagai Peserta Pemilu. Untuk anggota DPD terdiri atas calon anggota DPD, orang seorang, dan organisasi yang ditunjuk oleh Peserta Pemilu anggota DPD.

Peserta kampanye pemilu terdiri dari anggota masyarakat atau para simpatisan yang mendukukung calon anggota DPR, DPD, dan DPRD atau partai politik untuk memenangkan Pemilihan Umum.

Petugas kampanye: seluruh petugas yang memfasilitasi pelaksanaan kampanye, diangkat dan diberhentikan oleh Pengurus Parpol sesuai tingkatannya, bertugas memfasilitasi pelaksanaan kampanye, bertanggungjawab terhadap 
kelancaran, keamanan dan ketertiban jalannya kampanye dan didaftarkan kepada KPU sesuai tingkatannya. sejak 3 (tiga) hari setelah Partai Politik ditetapkan sebagai Peserta Pemilu.

6. Peserta pemilu yang dengan sengaja memberikan keterangan yang tidak benar dalam laporan dana kampanye (pasal 280)

Peserta Pemilu yang dengan sengaja memberikan keterangan tidak benar dalam laporan dana Kampanye Pemilu sebagaimana dimaksud dalam Pasal 134 ayat (1) dan ayat (2) serta Pasal 135 ayat (1) dan ayat (2) dipidana dengan pidana kurungan paling lama 1 (satu) tahun dan denda paling banyak Rp12.000.000,00 (dua belas juta rupiah).

Yang dimaksud pasal 134 dan pasal 135 dalam ketentuan pidana pada pasal 280 ini yaitu sebagai berikut:

\section{Pasal 134}

(1) Partai politik Peserta Pemilu sesuai dengan tingkatannya wajib memberikan laporan awal dana kampanye Pemilu dan rekening khusus dana Kampanye Pemilu kepada KPU, KPU provinsi, dan KPU Kabupaten atau Kota paling lambat 14 (empat belas) hari sebelum hari pertama jadwal pelaksanaan Kampanye Pemilu dalam bentuk rapat umum.

(2) Calon anggota DPD Peserta Pemilu wajib memberikan laporan awal dana Kampanye Pemilu dan rekening khusus dana Kampanye Pemilu kepada KPU melaui KPU provinsi paling lambat 14 (empat belas) hari sebelum hari pertama jadwal pelaksanaan Kampanye Pemilu dalam bentuk rapat umum.

\section{Pasal 135}

(1) Laporan dana kampanye Partai Politik Peserta Pemilu yang meliputi penerimaan dan pengeluaran wajib disampaikan kepada kantor akuntan publik yang ditunjuk oleh KPU paling lama 15 (lima belas) hari sesudah hari pemungutan suara. 
(2) Laporan dana kampanye calon anggota DPD Peserta Pemilu yang meliputi penerimaan dan pengeluaran wajib disampaikan kepada kantor akuntan publik yang ditunjuk oleh KPU paling lama 15 (lima belas) hari sesudah hari pemungutan suara.

\section{Analisis terhadap Pelanggaran Kampanye Pemilu Perspektif} Fiqh Jinâyah

Dalam pelanggaran kampanye Pemilu tidak terlepas dari peran pelaksana kampanye, petugas kampanye, dan peserta kampanye yang sangat rentan untuk melakukan pelanggaran dalam berkampanye Pemilu legislatif, karena yang \mudah untuk melakukan kampanye Pemilu merupakan dari ketiga pelaku kampanye tersebut. Jadi dengan peraturan kampanye Pemilu yang telah dijelaskan dalam Undang-undang Nomor 8 Tahun 2012 tentang Pemilihan Umum, seluruh kebijakan kampanye akan dapat dijalankan sebagaimana mestinya.

Ketika mengamati pelaksanaan kampanye Pemilu 2014, memang telah diatur dan dijelaskan dalam Undang-undang Pemilu (UU Nomor 8 Tahun 2012 tentang Pemilihan Umum), namun dalam pelaksanaannya masih banyak pelanggaran kampanye Pemilu yang dilakukan oleh parpol maupun perorangan. Sehingga dengan banyaknya pelanggaran yang dilakukan dapat diartikan bahwa nilai ketaatan bangsa Indonesia sangat minim terhadap Undang-undang Pemilu yang dibuat oleh Dewan Perwakilan Rakyat. Sedangkan dalam Al-qur'an Allah swt berfirman dalam surah An-nisa' ayat 59, yang berbunyi:

"Hai orang-orang yang beriman, taatilah Allah dan taatilah Rasul (Nya), dan ulil amri di antara kamu. kemudian jika kamu berlainan Pendapat tentang sesuatu, Maka kembalikanlah ia kepada Allah (Al Quran) dan Rasul (sunnahnya), jika kamu benar-benar beriman kepada Allah 
dan hari kemudian. yang demikian itu lebih utama (bagimu) dan lebih baik akibatnya." 29

Dari ayat diatas terdapat suatu perintah untuk taat kepada Allah dan Rasulnya kemudian taat kepada ulil amri. Ulil amri merupakan pemimpin negara yang perlu ditaati selama mereka tidak menyeru dalam kemungkaran. Sebagaian ulama memahami kata ulil amri dengan makna sekelompok tertentu, yakni suatu lembaga yang berwenang menetapkan dan membatalkan sesuatu. Misalkan dalam hal pembentukan Undang-undang atau yang dinamai dengan ahlul halli wal aqdi.

Dalam penafsiran surah An-Nisa' ayat 59 di atas, kata ulil amri dapat diartikan dengan makna Dewan Perwakilan Rakyat. Karena jika dilihat dari tafsir ahlul halli wal aqdi yaitu sebagai lembaga perwakilan, maka keberadaannya sama dengan Dewan Perwakilan Rakyat di Indonesia.

Dengan demikian ketika menganalisa pelanggaran kampanye Pemilu dalam Undang-undang Pemilu, dapat ditransformasikan terhadap ketidaktaatan kepada ulil amri sebagaimana yang disebut alam surah An-Nisa' ayat 59. Hal ini disebabkan karena Undangundang Pemilu merupakan produk Dewan Perwakilan Rakyat (DPR), sedangkan DPR sendiri merupakan penjelmaan dari ahlul halli wal aqdi, karena dalam lembaga ini terdapat berbagai macam kalangan profesi yang mewakili rakyat, sehingga keberadaannya dapat disamakan dengan ahlul halli wal aqdi.

Selain itu pelanggaran kampanye Pemilu menurut figh jinâyah dapat dikelompokkan dalam sanksi jarimah. Dalam figh jinâyah, jarimah sendiri terdapat berbagai macam bentuk jarimah yaitu jarîmah hudūd, jarîmah qishas, jarîmah ta'zîr. Akan tetapi dari beberapa bentuk jarimah tersebut yang lebih relevan untuk menjatuhi sanksi menurut figh jinayah bagi pelaku pelanggaran kampanye Pemilu adalah sanksi jarîmah ta'zîr.

\footnotetext{
${ }^{29}$ Yayasan Penyelenggara Penterjemah dan Pentafsir Al-Qur'an, Al-Qur'an dan Terjemanya, 128.
}

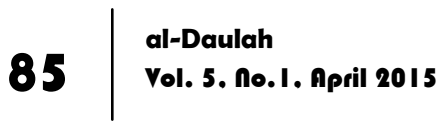


Pada prinsipnya hukuman ta'zîr hanya dikenakan pada perbuatan yang dianggap maksiat, akan tetapi syariat memberikan kelonggaran hukuman bagi perbuatan yang bukan maksiat apabila dikehendaki oleh kepentingan umum. Hal ini sangat berguna bagi ulil amri dalam permasalahan perkembangan masa dan perubahan tempat, yang tentu saja berkaitan dengan kemaslahatan umat. Oleh karena itu bentuk jarimah tidak dapat ditentukan sebelumnya, seperti pada jarîmah hudūd dan qishas diyat, karena kemaslahatan umum tidak dapat diprediksi sebelumnya dan sangat rentan terhadap perubahan. Adapaun persyaratan umum yang menjadi para meter jarîmah ta'zîr ini tergantung pada dua hal, yaitu; kepentingan dan ketertiban umum. Dan jika sifat-sifat tersebut (kepentingan dan ketertiban) sudah tidak ada lagi maka suatu perbuatan tersebut sudah tidak dianggap sebagai jarîmah. Hal ini juga menyebabkan tidak perlunya asas legalitas yang kaku bagi jarîmah ini. Bagi jarîmah ta'zîr diperlukan ketentuan-ketentuan yang bersifat elastis karena ada perubahan dan perkembangan tadi. Dan yang paling utama dalam permasalahan ini adalah semua perbuatan yang mempunyai sifat-sifat melawan kepentingan dan ketertiban umum akan mendapat hukuman, serta pelakunya sulit untuk menghindar dari jangkauan hukuman karena sifat elastisnya tadi.

Hukuman $t a^{\prime} z \hat{i} r$ mempunyai arti pendidikan dan pengajaran. Dari pengertian ini dapat kita pahami bahwa tujuan $t a^{\prime} z \hat{\imath} r$ adalah mengubah si pelaku menjadi baik kembali dan tidak melakukan kejahatan yang sama pada waktu yang lain dengan maksud pendidikan tersebut, keberadaan si pelaku setelah melakukan hukuman jarimah harus dipertahankan, si pelaku harus hidup setelah dijatuhkan hukuman agar tujuan pendidikan dapat tercapai. Oleh karena itu hukuman $t a^{\prime} z \hat{\imath} r$ yang dijatuhkan terhadap pelaku tidak sampai membinasakan jiwanya, sebab apabila dengan kematian si pembuat jarimah tujuan pendidikannya tidak akan tercapai. 
Dengan adanya konsep hukuman $t a^{\prime} z \hat{\imath} r$, maka segala pelanggaran kampanye pemilu yang terkait dengan aturan Undang-undang Nomor 8 Tahun 2012 tentang Pemilu, dapat dijerat dengan jarîmah ta'zîr. Hal ini disebabkan karena undangundang tersebut dibentuk dalam rangka menjaga kemaslahatan umum, dengan tujuan melaksanakan kampanye yang aman dan tertib. Maka dengan melakukan pelanggaran kampanye dalam undang-undang pemilu, bisa dikatakan berarti tidak menjaga ketertiban dan kepentingan umum.

Adapun sifat pelanggaran kampanye pemilu yang menjadi alasan dikenakannya perbuatan $t a^{\prime} z \hat{i} r$ adalah karena pelanggaran kampanye pemilu ini memiliki sifat melanggar aturan yang sudah ditetapkan. Adapun beberapa intisari yang dapat menjadi rujukan atas pelanggaran kampanye pemilu ini dalam jarîmah ta'zîr dibagi menjadi tiga bagian yakni; 1) Ta'zîr karena melakukan perbuatan maksiat, 2) ta'zîr karena melakukan perbuatan yang membahayakan kepentingan umum, serta 3) ta'zîr karena melakukan pelanggaran (mukhâlafah).

Seperti halnya pelanggaran dalam kampanye yang pertama yaitu: Mengganggu, mengacau atau menghalangi proses jalannya kampanye pemilu yang belangsung. Pelanggaran ini dapat masuk dalam jarimah ta'zîr yang berkategori sedang, karena telah melakukan perbuatan yang membahayakan kepentingan umum. Perbuatan-perbuatan yang masuk dalam jarimah ini tidak bisa ditentukan, karena perbuatan ini tidak diharamkan karena zatnya, melainkan karena sifatnya. Sifat yang menjadi alasan dikenakan hukuman adalah terdapat unsur merugikan kepentingan umum. Dalam hal merugikan kepentingan umum atau jarîmah ta'zîr yang dikategorikan sebagai pelanggaran yang sedang, menurut Abdul Qodir Awdah sanksi yang dapat dikenakan secara hukum shar'i adalah menyerahkannya kepada penguasa. Dapat juga sanksinya berupa hukuman pengucilan atau kurungan paling lama satu tahun kurungan penjara dan berupa tidak diikut sertakan kembali 
dalam suatu kegiatan kemasyarakatan. Sanksi ini dapat dikenakan karena merusak kemaslahatan umat.

Yang kedua: melakukan kampanye pemilu di luar jadwal yang sudah ditetapkan oleh peraturan yang berlaku. Pelanggaran ini termasuk dalam pelanggaran yang melanggar aturan perundang-undangan kampanye secara teknis. Melakukan kegiatan kampanye di luar ketentuan yang berlaku menurut Abdul Qodir Awdah adalah sama halnya dengan melakukan perbuatan jarîmah ta'zîr yang dikategorikan sebagai jenis jarîmah yang melanggar peraturan pemerintah. Jarîmah jenis ini termasuk kategori jarimah $t a^{\prime} z \hat{i} r$ ringan yang dapat dikanai sanksi hukuman diyat (denda atau kurungan paling lama satu tahun penjara) dan hukuman teguran serta peringatan.

Ketiga: melanggar larangan dalam kampanye pemilu, dalam hal ini ditujukan kepada Pegawai Negeri Sipil (PNS), Tentara Negara Indonesia (TNI), Polisi Republik Indonesia (POLRI), Kepala Desa dan perangkat desa yang ikut serta atau menjadi pelaksana atau petugas kampanye pemilu. Jarîmah ini menyangkut para aparatur negara atau yang disebut ulil amri maka sanksinya diserahkan pada penguasa dan termasuk dalam jarîmah ta'zîr sedang, karena menghianati amanah. Sanksi hukuman untuk jarîmah $t a^{\prime} z i \hat{r}$ yang dikategorikan $t a^{\prime} z \hat{i} r$ sedang ini adalah hukuman kurungan atau kawalan terbatas atau pengucilan. Di dalam hukum positif para aparatur negara yang melanggara dapat dikenakan hukuman kode etik dan pelanggaran pemilu.

Keempat: kesengajaan atau kelalaiannya para petugas kampanye, pelaksana kampanye, atau peserta kampanye yang mengakibatkan terganggunya pelaksanaan kampanye pemilu ditingkat desa atau kelurahan. Pelanggaran kampanye pemilu ini masuk dalam $t a^{\prime} z \hat{\imath} r$ ringan yang berpacu pada $t a^{\prime} z \hat{\imath} r$ melakukan pelanggaran, Dalam merumuskan $t a^{\prime} z \hat{i} r$ ini karena pelanggaran terda pat beberapa pandangan, yang pertama berpendapat bahwa orang yang meninggalkan yang mandub (sesuatu yang diperintahkan dan dituntut untuk dikerjakan) atau mengerjakan 
yang makruh (sesuatu yang dilarang dan dituntut untuk ditinggalkan) tidak dianggap melakukan maksiat, hanya saja mereka dianggap menyimpang atau pelanggaran dapat dikenakan ta'zîr.

Dan yang kelima yaitu: memberikan keterangan yang tidak benar dalam laporan dana kampanye pemilu. Sifat pelanggaran ini dapat masuk dalam $t a^{\prime} z i \hat{r}$ berat, karena telah melakukan perbuatan maksiat, yang dimaksud dengan maksiat adalah meninggalkan perbuatan yang diwajibkan dan melakukan perbuatan yang diharamkan. Misalnya : tidak membayar utang, memanipulasi hasil wakaf, sumpah palsu, riba, menolong pelaku kejahatan, memakan barang-barang yang diharamkan dll.

Di dalam fiqih jinâyah, memang belum ada peraturan yang baku terhadap pelanggaran kampanye. Namun, jarîmah ta'zîr merupakan jarimah yang lebih pantas diberikan kepada si pelaku pelanggaran kampanye Pemilu akan lebih memberikan efek jera yang mendidik bagi si pelaku itu sendiri. Karena pelanggaran kampanye Pemilu termasuk dalam pelanggaran terhadap ketertiban umum. Akan tetapi pemerintah (ulil amri) dapat memberikan hukuman yang sesuai, dengan tujuan agar pelaku dapat merasakan efek jera secara mendidik terhadap perilakunya sendiri yang melanggar peraturan dan tidak mengulangi pelanggaran yang sama. Ulil amri juga memiliki kewenangan yang luas untuk menetapkan suatu jarimah sesuai dengan kemaslahatan. Oleh karena itu hakim (ulil amri) boleh memberikan hukuman terhadap pelaku Jarimah yang tidak terdapat aturan dalam nas jika tuntutan kemaslahatan menghendakinya, dari sinilah digunakan kaidah:

Hukum ta'zîr berlaku sesuai dengan tuntutan kemaslahatan..$^{30}$

Adanya kaidah ini merupakan wujud dinamisasi pada Hukum Pidana Islam dimana kaidah ini menjawab bentuk-bentuk kejahatan baru yang tidak ada aturan dalam Al-qur'an dan al-

30 Jaih Mubarok dan Enceng Arif Faizal, Kaidah Fiqh Jinayah: Asas-Asas Hukum Pidana Islam, (Bandung: Pustaka Bani Quraisy, 2004), 48-49.

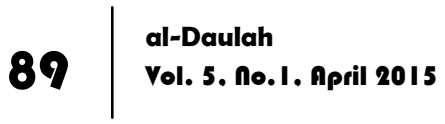


Hadis sehingga bentuk kejahatan baru yang dianggap merusak ketenangan dan ketertiban umum dapat dituntut dan dijatuhi hukuman pidana dengan merujuk kepada kebijakan ulil amri, dalam hal ini pemerintah Indonesia dengan Undang-Undang dan peraturan lainnya.

Penjatuhan pidana pada jarîmah ta'zîr bukan semata-mata sebagai pembalasan dendam, yang paling penting adalah pemberian bimbingan dan pengayoman. Ini sejalan dengan pendapat Imam Al Mawardi, bahwa "ta'zir adalah hukuman bagi tindak pidana yang belum ditentukan hukumannya oleh syarak yang bersifat mendidik". Maksud dari "mendidik" disini adalah untuk mencegah terjadinya maksiat pada masa yang akan datang. ${ }^{31}$

Akan tetapi dalam penjatuhan hukuman atau sanksi bagi pelaku tindak pidana pelanggaran Kampanye Pemilu, penulis mempunyai pandangan yang berbeda dalam penjatuhannya. Pelaku yang sudah melanggar ketentuan kampanye atau ketertiban umum tersebut dalam sanksi jarîmah ta'zîr ditambah dengan dijatuhi hukuman pengasingan, ${ }^{32}$ karena dalam penambahan hukuman tersebut menurut hemat penulis lebih memberikan efek jera dibandingkan hukuman yang hanya berupa pendidikan, denda atau kurungan (penjara). Akan tetapi dalam hal ini tetap dikembalikan kepada hakim (ulil amri) sebagai pemegang kewenangan dalam menjatuhkan hukuman.

Maka ketika pelaku pelanggar kampanye dijatuhi hukuman ta'zîr seperti yang telah dijelaskan di atas, semua ini bertujuan agar supaya proses pada masa kampanye dapat terselenggara dan berjalan dengan aman dan tertib tanpa melakukan pelanggaran kampanye yang tidak diinginkan oleh masyarakat maupun pengawas Pemilu, sehingga menjadikan kampanye Pemilu yang bersih dan bebas dari pelanggaran-pelanggaran yang sudah sering terjadi.

${ }^{3 !}$ Alie Yafie, Dkk, Ensiklopedi Hukum Pidana Islam, Jilid II, (Bogor: PT Kharisma IImu, t.t.), 178.

${ }^{32}$ Penjelasan ada pada BAB II dalam sub bab Macam-macam Sanksi Jarimah Ta'zir, 37. 


\section{Penutup}

Pelanggaran yang sering terjadi biasanya bersifat administratif dan berbentuk pelanggaran tindak pidana pemilu. Pelanggaran administrasi adalah pelanggaran tata cara dan mekanisme pemilu yang diatur di Undang-Undang. Sementara pelanggaran tindak pidana pemilu adalah semua tindak pidana yang diatur dalam UU Nomor 8 Tahun 2012 tentang Pemilu. Adapun hal-hal yang mencakup mengenai pelanggaran kampanye pemilu adalah sebagai berikut: 1) Mengganggu, mengacau atau menghalangi proses jalannya kampanye pemilu yang belangsung. 2) Melakukan kampanye pemilu di luar jadwal yang sudah ditetapkan oleh peraturan yang berlaku. 3) Melanggar larangan dalam kampanye pemilu, dalam hal ini ditujukan kepada Pegawai Negeri Sipil (PNS), Tentara Negara Indonesia (TNI), Polisi Republik Indonesia (POLRI), Kepala Desa dan perangkat desa yang ikut serta atau menjadi pelaksana atau petugas kampanye pemilu. 4) Kesengajaan atau kelalaiannya para petugas kampanye, pelaksana kampanye, atau peserta kampanye yang mengakibatkan terganggunya pelaksanaan kampanye pemilu ditingkat desa atau kelurahan. 5) Memberikan keterangan yang tidak benar dalam laporan dana kampanye pemilu. Dari beberapa ketentuan yang mencakup mengenai pelanggaran kampanye pemilu tersebut terdapat sanksi yang rata-rata berupa sanksi kurungan dan denda. Adapaun sanksi kurungan dalam pelanggaran kampanye Pemilu yang paling lama yaitu 1 tahun kurungan penjara, yang paling ringan selama 6 bulan kurungan. Sedangkan dalam hukuman dendanya yang paling besar yaitu sebanyak 12.000.000,- dan yang paling ringan sebanyak 6.000.000,--

Dalam perspektif Figh Jinayah, pelanggaran kampanye pemilu masuk dalam kategori Jarîmah Ta'zîr meskipun Fiqh Jinâyah tidak ada aturan yang berlaku di dalamnya mengenai pelanggaran kampanye. adapun pelanggaran kampanye pemilu yaitu: 1) Mengganggu, mengacau atau menghalangi proses jalannya kampanye pemilu yang belangsung. 2) Melakukan kampanye 
pemilu di luar jadwal yang sudah ditetapkan oleh peraturan yang berlaku. 3) Melanggar larangan dalam kampanye pemilu, dalam hal ini ditujukan kepada Pegawai Negeri Sipil (PNS), Tentara Negara Indonesia (TNI), Polisi Republik Indonesia (POLRI), Kepala Desa dan perangkat desa yang ikut serta atau menjadi pelaksana atau petugas kampanye pemilu. 4) Kesengajaan atau kelalaiannya para petugas kampanye, pelaksana kampanye, atau peserta kampanye yang mengakibatkan terganggunya pelaksanaan kampanye pemilu ditingkat desa atau kelurahan. 5) Memberikan keterangan yang tidak benar dalam laporan dana kampanye pemilu. Akan tetapi dari beberapa macam pelanggaran kampanye ini dapat dikorelasikan seperti halnya berupa ta'zîr karena melakukan perbuatan maksiat, ta'zîr karena melakukan perbuatan yang membahayakan kepentingan umum, serta $t a^{\prime} z \hat{i} r$ karena melakukan pelanggaran (mukhâlafah). Sehingga pemerintah (Ulil Amri) dapat memberikan hukuman yang sesuai, dengan tujuan agar pelaku dapat merasakan efek jera secara mendidik terhadap perilakunya sendiri yang melanggar peraturan kampanye Pemilu dan tidak mengulangi pelanggaran yang sama. Oleh karena itu pelaku pelanggaran kampanye Pemilu menurut Jarimah $T a^{\prime} z \hat{\imath} r$ tetap diserahkan sepenuhnya kepada hakim (Ulil Amri) yang mempunyai kewenangan dalam memberikan hukuman terhadap pelaku jarîmah atau pelaku pelanggaran kampanye Pemilu yang tidak terdapat aturan dalam nas jika tuntutan kemaslahatan menghendakinya.

\section{Daftar Pustaka}

Ali, Mohammad. http://www.kamusbahasaindonesia.org/ pelanggaran diunduh pada tanggal 30-06-2014

Anwar, M. Khoirul dan Vina Selviana. Perilaku Partai Politik. Malang: UMM Press, 2006.

Cangara, Hafied. Komunikasi Politik: Konsep, Teori dan Strategi. Jakarta: Rajawali Pers, 2011. 
Donald, Perulian. Menggugat Pemilu. Jakarta: Pustaka Sinar Harapan, 1997.

Faizurrahman, Republika, "Curi Start Kampanye, Caleg PKPI

Divonis Satu Bulan Penjara" dalam

http://www.beritadewan.com/divonis-curi-start-kampanye-

sutiyoso-tuntut-yang-beriklan-di-televisi-juga-ditindak/

diakses pada 20 Maret 2014.

Hamzah, Andi. KUHP dan KUHAP. Jakarta, Rineka Cipta, 2003.

Haq, Wahdanal. "Kampanye dalam Islam" dalam http://wahdanalhaq.blogspot.com/2011/01/kampanye-dalamislam/, diakses pada 05 April 2014.

Heryanto, Gun Gun. Komunikasi Politik Sebuah Pengantar. Bogor:

Ghalia Indonesia, 2013.

Imawan, Riswandha. Membedah Politik Orde Baru. Yogyakarta: Pustaka Pelajar, 1998.

Mubarok, Jaih dan Enceng Arif Faizal. Kaidah Figh Jinayah: AsasAsas Hukum Pidana Islam. Bandung: Pustaka Bani Quraisy, 2004.

Muhaki. "Mekanisme Suara Terbanyak bagi Pemilu Legislatif (Studi Siyasah Dusturiyah)" dalam Al-Daulah Jurnal Hukum dan Perundangan Islam, Vol. I, No. 2, Tahun 2011.

Mulyadi, Dedi. Perbandingan Tindak Pidana Pemilu Legislatif Dalam Perpektif Hukum di Indonesia. Bandung: Refika Aditama, 2013.

Nuril, Wildan. http://www.artikata.com diunduh pada tanggal 2006-2014

Priyanto. "Analisis Hukum Islam terhadap pelanggaran Undangundang nomor 31 tahun 2002 tentang Partai Politik dan Undang-Undang 12 tahun 2003 tentang Pemilu" (Skripsi-IAIN Sunan Ampel, Surabaya, 2004).

Rusli, M. Karim. Pemilu Demokratis Kompetitif. Yogyakatra : PT. Tiara Wacana, 1991.

Sanit, Arbi. Partai, Pemilu dan Demokrasi. Jakarta : Pustaka Pelajar, 1997. 
Surbakti, Ramlan, dkk. Penanganan Pelanggaran Pemilu. Jakarta: Kemitraan, 2011.

Tutik, Titik Triwulan. Konstruksi Hukum Tata Negara Indonesia Pasca Amandemen UUD 1945. Jakarta: Kencana, 2011.

Undang-undang Nomor 8 Tahun 2012 tentang Pemilihan Umum Anggota Dewan Perwakilan Rakyat, Dewan Perwakilan Daerah, Dewan Perwakilan Rakyat Daerah.

Undang-undang Nomor 8 Tahun 2012 tentang Pemilihan Umum Anggota DPR, DPD, DPRD.

Yafie, Alie, dkk. Ensiklopedi Hukum Pidana Islam. Jilid II, Bogor: PT Kharisma Ilmu, t.t.

Yaqin, Ainul. http://www.blogger.com/post- diakses pada tanggal 20-06-2014.

Yayasan Penyelenggara Penterjemah dan Pentafsir Al-Qur'an. AlQur'an dan Terjemahnya. Jakarta: 1971. 